\title{
Analysis of the Mycosporine-Like Amino Acid (MAA) Pattern of the Salt Marsh Red Alga Bostrychia scorpioides
}

\author{
Maria Orfanoudaki ${ }^{1}{ }^{\oplus}$, Anja Hartmann ${ }^{1, *}$, Julia Mayr ${ }^{1}$, Félix L. Figueroa ${ }^{2}{ }^{\oplus}$, Julia Vega ${ }^{2}{ }^{\oplus}$, John West ${ }^{3}$, \\ Ricardo Bermejo ${ }^{4}\left(\mathbb{D}\right.$, Christine Maggs ${ }^{5}$ and Markus Ganzera ${ }^{1}$ (D) \\ 1 Institute of Pharmacy/Pharmacognosy, University of Innsbruck, Innrain 80-82, 6020 Innsbruck, Austria; \\ orfmaria@gmail.com (M.O.); Julia.mayr90@gmail.com (J.M.); markus.ganzera@uibk.ac.at (M.G.) \\ 2 Experimental Centre Grice-Hutchinson, Institute of Blue Biotechnology and Development (IBYDA), \\ University of Malaga, 29004 Malaga, Spain; felix_lopez@uma.es (F.L.F.); juliavega@uma.es (J.V.) \\ 3 School of BioSciences, University of Melbourne, Parkville, VIC 3010, Australia; jwest@unimelb.edu.au \\ 4 Earth and Ocean Sciences, School of Natural Sciences and Ryan Institute, National University of Ireland, \\ H91 TK33 Galway, Ireland; ricardo.bermejo@uca.es \\ 5 Medical Biology Centre, School of Biological Sciences, Queen's University Belfast, Belfast BT22 1PF, UK; \\ cmaggs@bournemouth.ac.uk \\ * Correspondence: anja.hartmann@uibk.ac.at; Tel.: +43-512-507-58430
}

check for updates

Citation: Orfanoudaki, M.; Hartmann, A.; Mayr, J.; Figueroa, F.L.; Vega, J.; West, J.; Bermejo, R.; Maggs,

C.; Ganzera, M. Analysis of the

Mycosporine-Like Amino Acid (MAA) Pattern of the Salt Marsh Red Alga Bostrychia scorpioides. Mar. Drugs 2021, 19, 321. https://doi.org/ $10.3390 /$ md19060321

Academic Editor: Bill J. Baker

Received: 31 March 2021

Accepted: 28 May 2021

Published: 31 May 2021

Publisher's Note: MDPI stays neutral with regard to jurisdictional claims in published maps and institutional affiliations.

Copyright: (c) 2021 by the authors. Licensee MDPI, Basel, Switzerland. This article is an open access article distributed under the terms and conditions of the Creative Commons Attribution (CC BY) license (https:/ / creativecommons.org/licenses/by/ $4.0 /)$.

\begin{abstract}
This study presents the validation of a high-performance liquid chromatography diode array detector (HPLC-DAD) method for the determination of different mycosporine-like amino acids (MAAs) in the red alga Bostrychia scorpioides. The investigated MAAs, named bostrychines, have only been found in this specific species so far. The developed HPLC-DAD method was successfully applied for the quantification of the major MAAs in Bostrychia scorpioides extracts, collected from four different countries in Europe showing only minor differences between the investigated samples. In the past, several Bostrychia spp. have been reported to include cryptic species, and in some cases such as B. calliptera, B. simpliciuscula, and B. moritziana, the polyphyly was supported by differences in their MAA composition. The uniformity in the MAA composition of the investigated B. scorpioides samples is in agreement with the reported monophyly of this Bostrychia sp.
\end{abstract}

Keywords: Bostrychia scorpioides; mycosporine-like amino acids; bostrychines; method validation; HPLC-DAD

\section{Introduction}

Bostrychia scorpioides (Hudson) Montagne ex Kützing is one of the most common red macroalgae growing in coastal salt marshes in Europe [1], and the only one found in Europe of approximately 40 Bostrychia species that are known globally [2]. It occurs on rocks, mud, and wood structures and partially as tufts on halophytes such as Halimione portulacoides in the upper and middle intertidal zones [3]. It can survive for a long period when exposed to air $[1,4]$ by experiencing severe osmotic and desiccation stress. This taxon has been reported to produce different metabolites in comparison to other Rhodophyta, such as polyols, d-sorbitol, and d-dulcitol instead of the most common heterosides floridoside or digeneaside [5]. Moreover, unique mycosporine-like amino acids (MAAs) named bostrychines A-F occur instead of widely distributed derivatives such as porphyra-334 or shinorine [6].

MAAs are small, highly polar compounds that absorb UV radiation in the range of 310-365 nm [7]. They are composed of a cyclohexenone or a cyclohexenimine scaffold, carrying nitrogen or imino alcohol substituents [8]. They mainly play a photoprotective role, but they are also considered as osmoprotectants, scavengers of free oxygen radicals and protectants against desiccation and thermal stress [7-9]. According to several studies, the molecular diversity of Bostrychia species is greater than previously assumed, and this fact led to recircumscriptions of many species within the Bostrychieae [10]. It has been 
reported that some complexes include cryptic species and, in some cases, MAAs were used as chemotaxonomic markers for the identification of different chemotypes [11,12]. The unique bostrychines of B. scorpioides are completely absent in all other Bostrychia species and thus are very significant taxonomic characters. The numerous other chemicals of Bostrychia species have not yet been sufficiently assessed as taxonomic characters or, as yet, evaluated relative to the distinctly different habitats of these taxa. Careful investigations and publications are pending in contrast to reports on the chemodiversity and chemotaxonomy of other algal taxa, e.g., the presence of fatty acids in the family Selenastraceae (Chlorophyceae) [13], galactan structures in the family Gigartinaceae (Rhodophyceae) [14], acetogenins and linear or cyclized terpenoids in the family Cystoseiraceae (Phaeophyceae) [15], and bromophenols in Leathesia sp. (Chordariaceae, Ochrophyta) [16].

In this context, the main focus of the present study was to investigate the different MAA patterns in the salt marsh macroalga B. scorpioides. To investigate the phytochemical profile of different $B$. scorpioides samples and unravel possible geographic patterns, various isolates were collected from several coastal regions of Western Europe and analyzed with an HPLC-DAD method that was developed and validated for the quantification of the main MAAs in Bostrychia scorpioides.

Validation was carried out following the ICH guidelines based on specificity, linearity, precision, and accuracy. Optimal chromatographic separation was achieved in $40 \mathrm{~min}$ on a YMS-Pack Pro C18 RS $(150 \times 4.6 \mathrm{~mm}, 3 \mu \mathrm{m})$ column by using water and methanol as mobile phase, modified with $0.9 \%(v / v)$ formic acid and $0.1 \%(v / v)$ acetic acid. The assay's sensitivity, linearity $\left(R^{2} \geq 0.9996\right)$, precision (intraday precision $\leq 4.31 \%$; interday precision $\leq 4.81 \%$ ) and accuracy (recovery rates between $93.08 \%$ and $103.78 \%$ ) were confirmed, rendering it suitable for the quantitative analysis of the main MAAs. Finally, practical applicability was proven by assaying different Bostrychia scorpioides extracts.

\section{Results}

\subsection{Method Development}

\subsubsection{Sample Preparation}

Prior to sample analysis, optimum extraction and homogenization conditions were determined. A variety of extraction procedures (duration of the extraction or cycles of sonication) and solvents (water, and mixtures with different methanol content) were investigated. Ultrasound-assisted extraction of the plant material with $100 \%$ water as solvent was found to be most efficient, being the only procedure to enable the exhaustive extraction of all relevant compounds. Homogeneously powdered plant material required for reproducible measurements was only obtained after the use of a Mikro-Dismembrator (Sartorius, Göttingen, Germany). The efficiency of the applied extraction procedure was confirmed as follows: a sample was prepared as described in Section 4.4 and after the extraction of the plant material once more, the supernatant was analyzed by HPLC. As no quantifiable amounts of the marker compounds were found in this solution, the suitability and efficiency of the applied extraction procedure was proven.

\subsubsection{HPLC-DAD}

For the development of an improved HPLC method, different stationary phases were examined, one from Phenomenex (Synergi MAX-RP 80A, $150 \mathrm{~mm} \times 4.60 \mathrm{~mm}, 4 \mu \mathrm{m}$ ) and three from YMC (Triart C18, $150 \mathrm{~mm} \times 3.00 \mathrm{~mm}, 3 \mu \mathrm{m}$; YMC-Pack ODS column, $250 \mathrm{~mm} \times 4.60 \mathrm{~mm}, 5 \mu \mathrm{m}$; YMC-Pack Pro C-18 RS, $150 \mathrm{~mm} \times 4.60 \mathrm{~mm}, 3 \mu \mathrm{m})$. The last column yielded the best results in terms of overall separation efficiency; thus, it was selected for further improvement. 
Methanol and water have been commonly used as mobile phase for the HPLC separation of MAAs; however, even a very low percentage of methanol (1-2\%) already resulted in poor retention of the analytes. Thus, purely aqueous conditions for the first 15 minutes of the method were selected. Adding methanol thereafter was advantageous for the elution and separation of the less polar MAAs. The addition of acidic modifiers like acetic acid and formic acid or buffers, such as ammonium formate, drastically improved the peak shape and resolution. Finally, the selected modifiers, $0.9 \%(v / v)$ formic acid and $0.1 \%(v / v)$ acetic acid, resulted in the overall best peak symmetry and resolution; therefore, they were utilized for further experiments. Also, temperature played an important role in the resolution of closely eluting MAAs. The separation of compounds 5 and $\mathbf{6}$ was improved at $20^{\circ} \mathrm{C}$ while $30^{\circ} \mathrm{C}$ was the best in order to resolve bostrychine $\mathrm{B}$ from other (currently unknown) constituents. Finally, as a compromise, column temperature was set to $25^{\circ} \mathrm{C}$. Flow rate proved to be very important as well, especially for the separation of bostrychine $B$ from other unknown constituents. A lower flow rate of $0.55 \mathrm{~mL} \mathrm{~min}^{-1}$ was required to resolve them adequately.

\subsection{Method Validation}

Several validation parameters indicate that the developed method is suitable for the quantitation of compounds 1-6 (Figure 1) in red algae. Calibration curves for all standards were constructed by plotting the peak areas against standard compound concentrations following a linear least-square fit regression model. Calibration data presented in Table 1 indicate linearity of the method in the tested range with a determination coefficient $\left(R^{2}\right)$ higher than 0.9996 in all cases. For bostrychine A, sufficient material with purity over $95 \%$ was not available; therefore it was quantified according to the calibration data of the structurally most similar bostrychine C. Limits of detection (LOD) and limits of quantification (LOQ) ranged from $0.04 \mu \mathrm{g} \cdot \mathrm{mL}^{-1}$ to $0.22 \mu \mathrm{g} \cdot \mathrm{mL}^{-1}$ and from $0.13 \mu \mathrm{g} \cdot \mathrm{mL}^{-1}$ to $0.65 \mu \mathrm{g} \cdot \mathrm{mL}^{-1}$, respectively (Table 1 ). Assay precision was assured by repeatedly extracting and analyzing sample 1. Intraday precision was found to be better than $4.31 \%$ and interday variation below $4.81 \%$ for all analytes (Table 1 ).<smiles>COC1=C(N)C[C@@](O)(CO)CC1=NC(CCC(N)=O)C(=O)[O-]</smiles>

compound 1-bostrychine A<smiles>COC1=C(N[C@@H](C(=O)O)C(C)O)CC(O)(CO)C[C@H]1N[C@H](CCC(=O)O)C(=O)[O-]</smiles>

compound 4-bostrychine D<smiles>COC1=C(N)CC(O)(CO)CC1=NC(CCC(=O)O)C(=O)[O-]</smiles>

compound 2-bostrychine $\mathrm{C}$<smiles>COC1=C(NC(CCC(=O)O)C(=O)[O-])CC(O)(CO)CC1=NC[C@H](C)O</smiles>

compound 5-bostrychine E<smiles>COC1=C(NC(C(=O)O)C(C)O)CC(O)(CO)CC1=NCCCC(N)=O</smiles>

compound 3-bostrychine B<smiles>COC1=C(NC(C(=O)[O-])C(C)O)CC(O)(CO)CC1=NCCC(=O)O</smiles>

compound 6-bostrychine $\mathrm{F}$

Figure 1. The structures of compounds 1-6. 
Table 1. Validation parameters of the HPLC method.

\begin{tabular}{|c|c|c|c|c|c|}
\hline \multicolumn{6}{|c|}{ Calibration Data } \\
\hline Substance & $\begin{array}{l}\text { Regression } \\
\text { Equation }^{\text {a }}\end{array}$ & Coefficient of Determination & $\begin{array}{l}\text { Linearity } \\
\left(\mu \mathrm{g} \cdot \mathrm{mL}^{-1}\right)\end{array}$ & $\begin{array}{c}\text { LOD }^{c} \\
\left(\mu \mathrm{g} \cdot \mathrm{mL}^{-1}\right)\end{array}$ & $\begin{array}{c}\mathrm{LOQ}^{\mathrm{d}} \\
\left(\mu \mathrm{g} \cdot \mathrm{mL}^{-1}\right)\end{array}$ \\
\hline bostrychine C & $y=22248 x+1.4832$ & $\mathrm{R}^{2}=0.9996$ & $0.06-105.20$ & 0.07 & 0.23 \\
\hline bostrychine B & $y=29657 x+2.0058$ & $\mathrm{R}^{2}=0.9999$ & $0.11-71.40$ & 0.04 & 0.13 \\
\hline bostrychine D & $y=35033 x+8.1483$ & $\mathrm{R}^{2}=0.9997$ & $0.26-83.00$ & 0.13 & 0.40 \\
\hline bostrychine E & $y=42335 x+5.4806$ & $R^{2}=0.9999$ & $0.04-69.00$ & 0.10 & 0.29 \\
\hline bbostrychine F & $y=27415 x+3.7719$ & $\mathrm{R}^{2}=0.9999$ & $0.10-63.60$ & 0.22 & 0.65 \\
\hline \multicolumn{6}{|c|}{ Accuracy and Precision } \\
\hline \multicolumn{3}{|c|}{ Precision } & \multicolumn{2}{|c|}{ Accuracy $\mathrm{g}$} & \\
\hline Substance & Intraday ${ }^{\mathrm{e}}$ & Interday $f$ & Low & Medium & High \\
\hline bostrychine A & 2.45 & bostrychine $\mathrm{C}$ & $95.15 \pm 1.03$ & $103.06 \pm 0.18$ & $95.39 \pm 0.11$ \\
\hline bostrychine $\mathrm{C}$ & 3.49 & bostrychine B & $95.53 \pm 0.52$ & $95.15 \pm 2.99$ & $97.75 \pm 0.16$ \\
\hline bostrychine B & 1.97 & bostrychine $\mathrm{F}$ & $102.77 \pm 0.40$ & $95.15 \pm 0.72$ & $103.78 \pm 0.85$ \\
\hline bostrychine D & 3.78 & 3.60 & & & \\
\hline bostrychine E & 4.31 & 4.81 & & & \\
\hline
\end{tabular}

${ }^{\mathrm{a}} \mathrm{x}$ : concentration in $\mathrm{mg} \cdot \mathrm{mL}^{-1}, \mathrm{y}: \mathrm{AUC} ;{ }^{\mathrm{b}}$ linear range; ${ }^{\mathrm{c}}$ LOD: limit of detection; ${ }^{\mathrm{d}}$ LOQ: limit of Quantification; ${ }^{\mathrm{e}}$ relative standard deviation within one day based on the peak area in percent; ${ }^{\mathrm{f}}$ Relative standard deviation within three days based on peak area in percent; $g$ recovery rates in percent (mean $\pm R S D$ ).

For determination of accuracy, only three marker compounds were utilized due to the limited number of standards available. Recovery rates were assessed at three different concentration levels (low, medium, and high) and ranged from $93.08 \%$ to $103.78 \%$ (Table 1).

\subsection{Sample Analysis}

Seventeen batches of B. scorpioides were analyzed with the developed HPLC-DAD method. The results shown in Table 2 and Figure 2 indicate that all six reference compounds could be identified in these samples (matching retention times and UV spectra), but only five could be quantified since bostrychine $\mathrm{F}$ was always present in concentrations lower than the LOQ. It has to be noted that only small quantitative differences were observed among the samples. Compounds $\mathbf{1}$ and $\mathbf{3}$ were present in all samples. Bostrychine D was quantifiable only in specimens from France, while bostrychine F could only be detected in samples from the same country (France). The only culture sample (sample 14) did not contain bostrychine $\mathrm{E}$ in contrast to all others which were collected in the field. Additionally, this sample yielded only compounds $\mathbf{2}$ and $\mathbf{3}$, but at higher concentrations compared to field samples. 
Table 2. Quantitative HPLC-DAD results for compounds 1-6 in B. scorpioides samples; all values expressed as mg per g of dry material; free spaces correspond to non-detected compounds; bostrychine A (compound 1), bostrychine B (compound 3), bostrychine C (compound 2), bostrychine D (compound 4), bostrychine E (compound 5), and bostrychine F (compound 6).

\begin{tabular}{|c|c|c|c|c|c|c|}
\hline Sample & $\begin{array}{c}\text { Bostrychine A } \\
\text { (mg.g-1) } \\
(\text { (Srel\% a) }\end{array}$ & $\begin{array}{c}\text { Bostrychine C } \\
\left(\mathrm{mg} \cdot \mathrm{g}^{-1}\right) \\
(\mathrm{Srel} \%)\end{array}$ & $\begin{array}{c}\text { Bostrychine B } \\
\left(\mathrm{mg}^{-1}\right) \\
(\mathrm{Srel} \%)\end{array}$ & $\begin{array}{c}\text { Bostrychine D } \\
\left(\mathrm{mg}^{-1} \mathrm{~g}^{-1}\right) \\
(\mathrm{Srel} \%)\end{array}$ & $\begin{array}{c}\text { Bostrychine E } \\
\left.\left(\mathrm{mg}^{-1}\right)^{-1}\right) \\
(\text { Srel\%) }\end{array}$ & $\begin{array}{c}\text { Bostrychine F } \\
\left(\mathrm{mg}^{-1}\right) \\
(\mathrm{Srel} \%)\end{array}$ \\
\hline 1 & $2.04(2.91)$ & $0.40(4.43)$ & $3.30(2.06)$ & $0.20(3.60)$ & $0.31(4.81)$ & \\
\hline 2 & $1.8(1.10)$ & $0.14(2.80)$ & $3.15(0.75)$ & $<\mathrm{LOQ}^{\mathrm{b}}$ & $0.28(4.98)$ & \\
\hline 3 & $3.35(0.54)$ & $<\mathrm{LOQ}^{\mathrm{b}}$ & $6.30(0.66)$ & & $0.47(4.96)$ & \\
\hline 4 & $3.16(0.78)$ & $0.22(3.33)$ & $4.03(0.62)$ & $0.16(4.47)$ & $0.21(4.52)$ & $<\mathrm{LOQ}^{\mathrm{b}}$ \\
\hline 5 & $2.49(1.63)$ & $0.25(1.83)$ & $3.04(2.80)$ & $0.18(2.01)$ & $0.21(2.35)$ & $<\mathrm{LOQ}^{\mathrm{b}}$ \\
\hline 6 & $2.84(1.28)$ & $0.07(2.59)$ & $3.85(0.20)$ & $0.02(3.17)$ & $0.24(4.24)$ & \\
\hline 7 & $2.17(0.36)$ & $0.16(4.38)$ & $3.49(0.49)$ & $0.11(3.62)$ & $0.17(2.10)$ & \\
\hline 8 & $1.87(0.29)$ & $<$ LOQ & $2.35(0.42)$ & & $0.14(2.15)$ & \\
\hline 9 & $0.88(2.31)$ & $1.76(3.00)$ & $1.10(3.37)$ & $0.73(4.47)$ & $0.33(4.26)$ & $<\mathrm{LOQ}^{\mathrm{b}}$ \\
\hline 10 & $1.63(0.50)$ & & $3.14(0.41)$ & & $0.28(5.16)$ & \\
\hline 11 & $1.46(1.66)$ & $0.11(4.17)$ & $1.95(2.50)$ & & $0.16(4.42)$ & \\
\hline 12 & $8.05(0.47)$ & $<\mathrm{LOQ}^{\mathrm{b}}$ & $2.04(0.26)$ & & $0.11(4.86)$ & \\
\hline 13 & $1.96(0.96)$ & $0.30(3.95)$ & $1.14(1.03)$ & $<\mathrm{LOQ}^{\mathrm{b}}$ & $0.08(4.90)$ & \\
\hline 14 & $4.42(1.73)$ & & $6.44(0.74)$ & & & \\
\hline 15 & $1.53(1.31)$ & $0.14(2.41)$ & $1.11(0.65)$ & $<\mathrm{LOQ}^{\mathrm{b}}$ & $0.09(3.44)$ & \\
\hline 16 & $2.49(0.61)$ & & $5.66(0.27)$ & & $0.18(3.40)$ & \\
\hline 17 & $1.42(1.29)$ & & $3.94(0.52)$ & & $0.39(1.73)$ & \\
\hline
\end{tabular}

${ }^{a}$ Relative standard deviation; ${ }^{b}$ Concentration was higher than the limit of detection but lower than the limit of quantification.

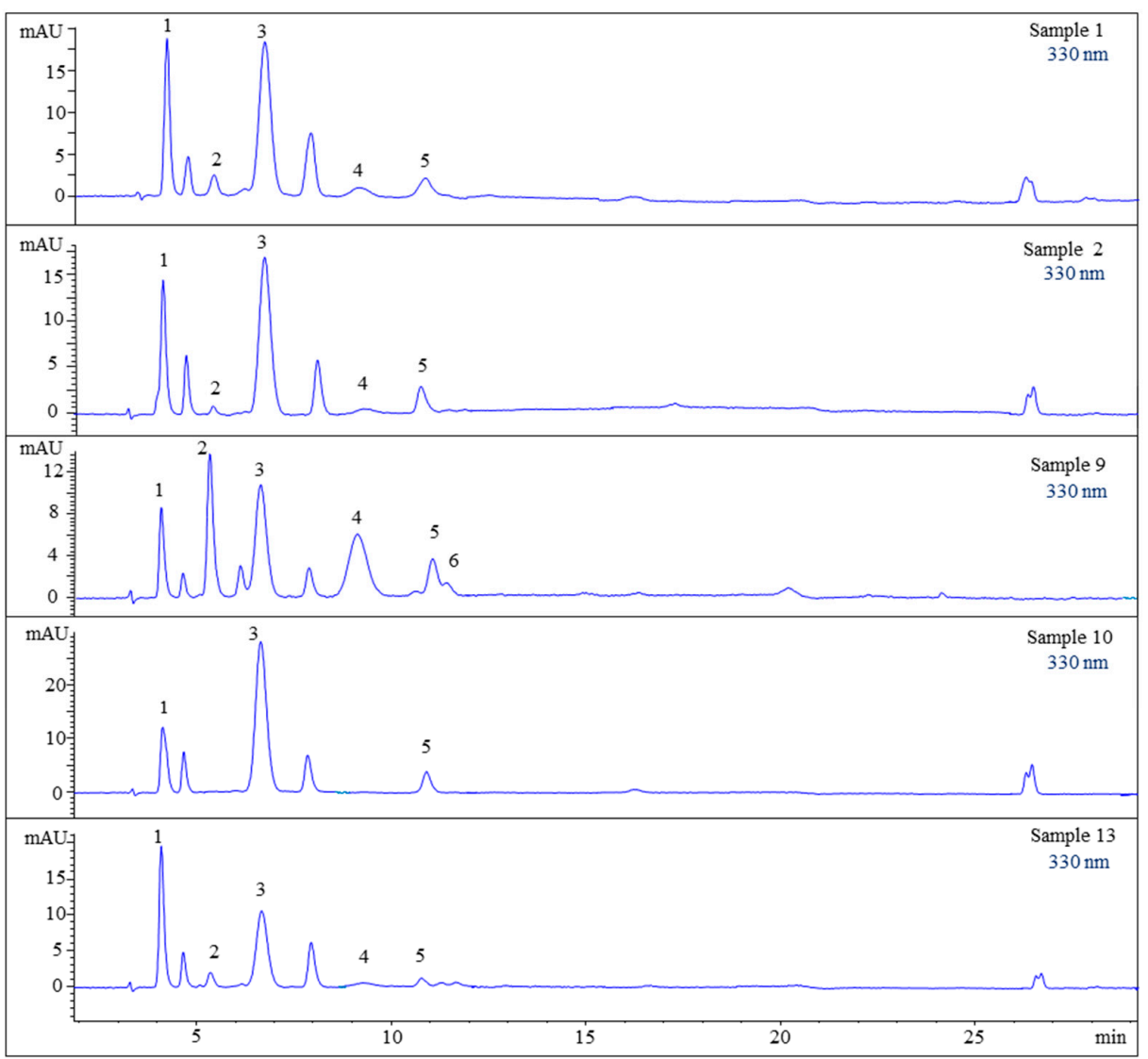

Figure 2. HPLC chromatograms of selected B. scorpioides samples. Assignment of the compounds is according to Figure 1. 


\section{Discussion}

In the present study, the MAA pattern of the red macroalga B. scorpioides was investigated. The respective compounds have already been reported previously by the same authors, and in the current work an HPLC-DAD method was developed and validated for the quantification of the major MAAs in Bostrychia scorpioides extracts for the first time. Satisfactory validation data for all tested parameters, including sensitivity, linearity, precision, and accuracy, as well as practical applicability, render the developed method a useful and reliable tool for the determination of MAAs in B. scorpioides.

In the past, a few studies focused on the quantitative and qualitative analysis of mycosporine-like amino acids and the most common technique is reversed-phase HPLC using C-8 and C-18 stationary phases [17-20]. Capillary electrophoresis (CE) and hydrophilic interaction liquid chromatography (HILIC) have also been described [21,22]. The major disadvantage of most studies is the low number of examined analytes with the exception of the study presented by Carreto et. al (2005) [23], who used two C18 columns connected in series for the analysis of more than 20 MAAs [17-22]. In general, the main problem in MAA analysis is the low retention of these metabolites on the column material, which results in low resolution and selectivity, especially when a large number of MAAs are analyzed. A prior study by some of the co-authors led to the method development and validation of an HPLC method that allowed the quantification of the 12 most common MAAs of Rhodophyta in 35 min using a YMC-Pack ODS column [12]. However, bostrychines of $B$. scorpioides extracts were not properly resolved with this method. As a consequence, the development of a new HPLC method was necessary due to the significance of these metabolites as chemotaxonomic markers.

Compared to all other Bostrychia spp., which are completely absent in Europe, $B$. scorpioides occupies intertidal habitats of the European Atlantic coast, and shows a unique MAA composition, producing none of the common MAAs such as porphyra-334, palythinethreonine, aplysiapalythine $\mathrm{A}$, asterina- 330 or shinorine, which are present in most of the other species $[6,12,24]$. Thus, bostrychines are very significant chemotaxonomic characters allowing the discrimination of this species. MAAs have been used in the past as biochemical indicators of taxonomy, e.g., for the discrimination of Grateloupia sp. of the Iberian Peninsula [25], for chemotaxonomic studies in the Prasiola-clade (Trebouxiophyceae, Chlorophyta) [26], or for the identification of cryptic species in the Bostrychia genus [11,12]. There are two proposed pathways for MAA biosynthesis, both identifying 4-deoxygadusol (4-DG) as the precursor of MAAs: the shikimate pathway and the pentose phosphate pathway [27]. Bostrychines contain the cyclohexenimine scaffold, which is common among MAAs produced by other red algae; however, the combination of amino acids in the side chains of bostrychines, mainly glutamine, glutamic acid or threonine, is not found in other MAAs. The reason for the presence of these specific amino acids may be because of different roles of these MAAs in the alga [7] or variations in their biosynthetic pathways, especially in late biosynthesis steps when amino-moieties are added to the core [28].

Even if the quantitative results were similar, small differences could be observed among the $B$. scorpioides samples analyzed. Compounds $\mathbf{1}$ and $\mathbf{3}$ were always the main MAAs; however, samples from France seemed to produce a higher variety of compounds compared to specimens from the UK, Ireland, and Spain. Moreover, the only sample provided from culture contained the highest concentration of bostrychine $\mathrm{C}$ as well as the second-highest concentration of bostrychine $\mathrm{A}$, but it did not produce bostrychine $\mathrm{E}$, which was found in all the field samples. This may be explained by the absence of desiccation stress, lower UV exposure due to the use of LEDs during cultivation, or differences in the concentration of nutrients in the culture medium.

In contrast to other Bostrychia spp. such as B. calliptera and B. simpliciuscula, which are reported to be polyphyletic and show distinct differences in their MAA composition [11,12], no qualitative difference was found in the MAA pattern of the monophyletic species $B$. scorpioides. 


\section{Materials and Methods}

\subsection{Plant Material}

Some of the authors (Maria Orfanoudaki, Félix L. Figueroa, Julia Vega, John West, Ricardo Bermejo, Christine Maggs) collected and morphologically identified the isolates, using their taxonomic expert knowledge in conjunction with standard identification keys [2,22]. Voucher samples of specimens 1-13 and 15-17 are deposited at the Department of Pharmacognosy, University of Innsbruck, Austria, and sample 14 at the School of BioSciences, University of Melbourne, Victoria, Australia. Further information regarding collection date and place are summarized in Table S1.

\subsection{Chemicals}

Methanol had pro-analysis (p.a) quality and was purchased from Merck (Darmstadt, Germany). Formic acid and acetic acid were obtained from VWR International (Vienna, Austria). A Sartorius Arium ${ }^{\circledR} 611$ UV (Sartorius, Göttingen, Germany) purification system was used for the production of ultrapure water.

\subsection{MAA Isolation}

The isolation of the standard compounds was described previously [6]. Assignment of the compounds is as follows: bostrychine A (compound 1), bostrychine B (compound 3), bostrychine $\mathrm{C}$ (compound 2), bostrychine $\mathrm{D}$ (compound 4), bostrychine $\mathrm{E}$ (compound 5), and bostrychine F (compound 6). Original NMR and UV spectra are shown in the supplementary materials (Figures S1-S39). The identity of the standards was determined by NMR, and MS, and their purity was found to be higher than $95 \%$. NMR experiments were conducted on a Bruker Avance II 600 spectrometer (Bruker, Karlsruhe, Germany) operating at $600.19\left({ }^{1} \mathrm{H}\right)$ and $150.91 \mathrm{MHz}\left({ }^{13} \mathrm{C}\right)$. The isolated compounds were dissolved in deuterated water from Euriso-Top (Saint Aubin, France) using tetramethylsilane (TMS) as an internal standard.

\subsection{HPLC Sample Preparation}

For the preparation of each sample, $100 \mathrm{mg}$ of B. scorpioides plant material was frozen in liquid nitrogen and homogenized using a Mikro-Dismembrator (Sartorius, Göttingen, Germany). The homogenization procedure was done separately for each of the different experiments (quantitation, precision, and accuracy). For extraction, $7.0 \mathrm{~mL}$ of water was added to the plant material, the sample was mixed on a Vortex mixer (VWR, Vienna, Austria) and afterwards extracted in an ultrasonic bath (15 min at room temperature). After centrifugation at $2000 \times g$ for $2 \mathrm{~min}$ the supernatant was placed in a $25 \mathrm{~mL}$ volumetric flask. This procedure was repeated twice and subsequently the flask was filled up to the final volume with the extraction solvent. Finally, the sample solution was filtered through $0.45 \mu \mathrm{m}$ Phenex-RC $4 \mathrm{~mm}$ syringe filters (Phenomenex, Torrance, CA, USA).

\subsection{HPLC-DAD Analysis}

HPLC analyses were performed on an Agilent 1100 series HPLC instrument, equipped with a quaternary pump, an autosampler, a column oven, and a photodiode array detector (Agilent, Waldbronn, Germany). Optimum separation was achieved on a YMS-Pack Pro C18 RS $(150 \times 4.6 \mathrm{~mm}, 3 \mu \mathrm{m})$ column from YMC, guarded with an in-line filter and using a mobile phase consisting of $0.9 \%(v / v)$ formic acid and $0.1 \%(v / v)$ acetic acid in water (A) and methanol (B). The applied gradient was as follows: $0 \% \mathrm{~B}$ at $0 \mathrm{~min}, 0 \% \mathrm{~B}$ at $15 \mathrm{~min}, 10 \%$ $\mathrm{B}$ at $23 \mathrm{~min}, 15 \% \mathrm{~B}$ at $30 \mathrm{~min}$, and $98 \% \mathrm{~B}$ at $35 \mathrm{~min}$, and held at this composition for $5 \mathrm{~min}$ (total runtime of $40 \mathrm{~min}$ ); for the next $15 \mathrm{~min}$ the column was equilibrated under initial conditions. Flow rate, temperature, and injection volume were adjusted to $0.55 \mathrm{~mL} \cdot \mathrm{min}^{-1}$, $25^{\circ} \mathrm{C}$, and $4.0 \mu \mathrm{L}$. The detection wavelength was set to $330 \mathrm{~nm}$. 


\subsection{Calibration and Method Validation}

The developed HPLC method was validated as per ICH guidelines. All validation results are summarized in Table 1.

\subsubsection{Linearity, Limit of Detection (LOD), and Limit of Quantification (LOQ)}

Standard stock solutions were prepared by separately weighting and dissolving compounds 2-6 in 100\% water. At least nine calibration levels were prepared from each stock solution by dilution with pure water, and each level was assayed in triplicate (calibration data are presented in Table 1). Plotting the peak areas versus the concentrations of each analyte resulted in the generation of calibration curves. The regression parameters (intercept, slope, and determination coefficient $\left(\mathrm{R}^{2}\right)$ ) were calculated by linear regression analysis using Microsoft Excel. The LOD and LOQ values for each analyte were calculated utilizing only the lowest four dilution levels. LOD is defined as 3.3 times the residual standard deviation of the regression line divided by the slope of the calibration curve, whereas the LOQ corresponds to 10 times the residual standard deviation divided by the slope.

\subsubsection{Precision and Accuracy}

Analysis of three individually homogenized and prepared extracts of sample 1 on three consecutive days in triplicate assured the precision of this method. Intra- and interday assay variance was expressed as the relative standard deviation (RSD) of the replicate quantitative measurement of compounds 2-6. Accuracy was determined by recovery experiments at three different concentration levels (low, medium, high) for analytes 2, $\mathbf{3}$ and $\mathbf{6}$ since sufficient amounts of analytes 4 and $\mathbf{5}$ were not available for spiking experiments. For this purpose, individually homogenized portions of sample 1 were spiked with known amounts of analytes 2, 3 and $\mathbf{6}$ prior to sample workup. All samples were prepared in triplicate.

Supplementary Materials: The following is available online at https://www.mdpi.com/article/ 10.3390/md19060321/s1: Table S1: Overview of the investigated B. scorpioides samples, including collection sites and dates, and NMR and UV spectra of the bostrychines. Figure S1. ${ }^{1} \mathrm{H}$ NMR spectrum of bostrychine $\mathrm{A}$ in $\mathrm{D}_{2} \mathrm{O}$ at $400 \mathrm{MHz}$. Figure S2. COSY spectrum of bostrychine $\mathrm{A}$ in $\mathrm{D}_{2} \mathrm{O}$ at $400 \mathrm{MHz}$. Figure S3. HSQC spectrum of bostrychine A in $\mathrm{D}_{2} \mathrm{O}$ at $400 \mathrm{MHz}$. Figure S4. HMBC spectrum of bostrychine $\mathrm{A}$ in $\mathrm{D}_{2} \mathrm{O}$ at $400 \mathrm{MHz}$. Figure $55 .{ }^{13} \mathrm{C}$ NMR spectrum of bostrychine $\mathrm{A}$ in $\mathrm{D}_{2} \mathrm{O}$ at $100 \mathrm{MHz}$. Figure 66 . NOESY spectrum of bostrychine $\mathrm{A}$ in $\mathrm{D}_{2} \mathrm{O}$ at $400 \mathrm{MHz}$. Figure S7. UV spectrum of bostrychine A. Figure S8. ${ }^{1} \mathrm{H}$ NMR spectrum of bostrychine $\mathrm{B}$ in $\mathrm{D}_{2} \mathrm{O}$ at $600 \mathrm{MHz}$. Figure S9. COSY spectrum of bostrychine $B$ in $\mathrm{D}_{2} \mathrm{O}$ at $600 \mathrm{MHz}$. Figure $\mathrm{S} 10$. HSQC spectrum of bostrychine $\mathrm{B}$ in $\mathrm{D}_{2} \mathrm{O}$ at $600 \mathrm{MHz}$. Figure $\mathrm{S11}$. HMBC spectrum of bostrychine $\mathrm{B}$ in $\mathrm{D}_{2} \mathrm{O}$ at $600 \mathrm{MHz}$. Figure $\mathrm{S} 12$. ${ }^{13} \mathrm{C}$ NMR spectrum of bostrychine $\mathrm{B}$ in $\mathrm{D}_{2} \mathrm{O}$ at $150 \mathrm{MHz}$. Figure $\mathrm{S} 13$. UV spectrum of bostrychine $\mathrm{B}$. Figure S14. ${ }^{1} \mathrm{H}$ NMR spectrum of bostrychine $\mathrm{C}$ in $\mathrm{D}_{2} \mathrm{O}$ at $600 \mathrm{MHz}$. Figure $\mathrm{S} 15$. COSY spectrum of bostrychine $\mathrm{C}$ in $\mathrm{D}_{2} \mathrm{O}$ at $600 \mathrm{MHz}$. Figure $\mathrm{S} 16$. HSQC spectrum of bostrychine $\mathrm{C}$ in $\mathrm{D}_{2} \mathrm{O}$ at $600 \mathrm{MHz}$. Figure S17. HMBC spectrum of bostrychine $\mathrm{C}$ in $\mathrm{D}_{2} \mathrm{O}$ at $600 \mathrm{MHz}$. Figure $\mathrm{S18} .{ }^{13} \mathrm{C}$ NMR spectrum of bostrychine $\mathrm{C}$ in $\mathrm{D}_{2} \mathrm{O}$ at $150 \mathrm{MHz}$. Figure $\mathrm{S} 19$. UV spectrum of bostrychine $\mathrm{C}$. Figure $\mathrm{S} 20 .{ }^{1} \mathrm{H}$ NMR spectrum of bostrychine $\mathrm{D}$ in $\mathrm{D}_{2} \mathrm{O}$ at $600 \mathrm{MHz}$. Figure $\mathrm{S} 21$. COSY spectrum of bostrychine $\mathrm{D}$ in $\mathrm{D}_{2} \mathrm{O}$ at $600 \mathrm{MHz}$. Figure S22. HSQC spectrum of bostrychine $\mathrm{D}$ in $\mathrm{D}_{2} \mathrm{O}$ at $600 \mathrm{MHz}$. Figure S23. HMBC spectrum of bostrychine $\mathrm{D}$ in $\mathrm{D}_{2} \mathrm{O}$ at $600 \mathrm{MHz}$. Figure $\mathrm{S} 24 .{ }^{13} \mathrm{C}$ NMR spectrum of bostrychine $\mathrm{D}$ in $\mathrm{D}_{2} \mathrm{O}$ at $150 \mathrm{MHz}$. Figure S25. UV spectrum of bostrychine D. Figure S26. ${ }^{1} \mathrm{H}$ NMR spectrum of bostrychine $\mathrm{E}$ in $\mathrm{D}_{2} \mathrm{O}$ at $600 \mathrm{MHz}$. Figure $\mathrm{S} 27$. COSY spectrum of bostrychine $\mathrm{E}$ in $\mathrm{D}_{2} \mathrm{O}$ at $600 \mathrm{MHz}$. Figure S28. ${ }^{13} \mathrm{C}$ NMR spectrum of bostrychine $\mathrm{E}$ in $\mathrm{D}_{2} \mathrm{O}$ at $150 \mathrm{MHz}$. Figure S29. HSQC spectrum of bostrychine $\mathrm{E}$ in $\mathrm{D}_{2} \mathrm{O}$ at $600 \mathrm{MHz}$. Figure $\mathrm{S} 30$. $\mathrm{HMBC}$ spectrum of bostrychine $\mathrm{E}$ in $\mathrm{D}_{2} \mathrm{O}$ at 600 $\mathrm{MHz}$. Figure S31. NOESY spectrum of bostrychine $\mathrm{E}$ in $\mathrm{D}_{2} \mathrm{O}$ at $600 \mathrm{MHz}$. Figure $\mathrm{S} 32$. UV spectrum of bostrychine E. Figure S33. ${ }^{1} \mathrm{H}$ NMR spectrum of bostrychine $\mathrm{F}$ in $\mathrm{D}_{2} \mathrm{O}$ at $600 \mathrm{MHz}$. Figure $\mathrm{S} 34$. COSY spectrum of bostrychine $\mathrm{F}$ in $\mathrm{D}_{2} \mathrm{O}$ at $600 \mathrm{MHz}$. Figure $\mathrm{S} 35$. HSQC spectrum of bostrychine $\mathrm{F}$ in $\mathrm{D}_{2} \mathrm{O}$ at $600 \mathrm{MHz}$. Figure S36. HMBC spectrum of bostrychine $\mathrm{F}$ in $\mathrm{D}_{2} \mathrm{O}$ at $600 \mathrm{MHz}$. Figure $\mathrm{S} 37 .{ }^{13} \mathrm{C}$ NMR spectrum of bostrychine $\mathrm{F}$ in $\mathrm{D}_{2} \mathrm{O}$ at $150 \mathrm{MHz}$. Figure $\mathrm{S} 38$. NOESY spectrum of bostrychine $\mathrm{F}$ in $\mathrm{D}_{2} \mathrm{O}$ at $600 \mathrm{MHz}$. Figure S39. UV spectrum of bostrychine $\mathrm{F}$. 
Author Contributions: Conceptualization, M.O., A.H. and M.G.; methodology, M.O., A.H. and M.G.; validation, M.O. and J.M.; formal analysis, M.O., J.M., A.H. and M.G.; investigation, M.O., J.M., A.H. and M.G.; resources, J.W., R.B., F.L.F., J.V. and C.M.; writing-original draft preparation, M.O.; writing-review and editing, M.O., J.M., A.H., J.W., R.B., F.L.F., J.V., C.M. and M.G.; supervision, A.H. and M.G.; project administration, A.H. and M.G.; funding acquisition, A.H. and M.G. All authors have read and agreed to the published version of the manuscript.

Funding: This research was funded by the Austrian Science Fund (FWF), project no. P29671.

Institutional Review Board Statement: Not applicable.

Informed Consent Statement: Not applicable.

Data Availability Statement: Data is contained within the article or supplementary material.

Acknowledgments: The authors gratefully thank Moya O'Donnell (National University of Ireland, Galway, Ireland) for field assistance, Pilar Díaz (IEO · Centro Oceanográfico de A Coruña, Spain) for collection and identification of samples from Galicia and Michael Guiry, (National University of Ireland, Galway) for collection and identification of samples from Co. Clare, Ireland.

Conflicts of Interest: The authors declare no conflict of interest.

\section{References}

1. Ruiz-Nieto, M.; Fernández, J.A.; Niell, F.X.; Carmona, R. Mechanisms of Inorganic Carbon Acquisition in Two Estuarine Rhodophyceans: Bostrychia scorpioides (Hudson) Ex Kützing Montagne and Catenella caespitosa (Withering) L. M. Irvine. Photosynth. Res. 2014, 121, 277-284. [CrossRef]

2. Guiry, M.D.; Guiry, G.M. AlgaeBase; World-Wide Electronic Publication, National University of Ireland: Galway, Ireland, 2020; Available online: http:/ / www.algaebase.org (accessed on 24 March 2020).

3. Van Reine, W.F.P.; Sluiman, H.J. Red Algae Found on European Salt-Marshes. I. Bostrychia scorpioides (Rhodomelaceae). Aquat. Bot. 1980, 9, 323-342. [CrossRef]

4. Karsten, U.; Kirst, G.O. Incomplete Turgor Pressure Regulation in the "Terrestial" Red Alga, Bostrychia scorpioides (Huds.) Mont. Plant Sci. 1989, 61, 29-36. [CrossRef]

5. Karsten, U.; King, R.; Kirst, G. The Distribution of D-Sorbitol and D-Dulcitol in the Red Algal Genera Bostrychia and Stictosiphonia (Rhodomelaceae, Rhodophyta): A Re-Evaluation. Br. Phycol. Soc. 1990, 25, 363-366. [CrossRef]

6. Orfanoudaki, M.; Hartmann, A.; Miladinovic, H.; Nguyen, H.N.; Karsten, U.; Ganzera, M. Bostrychines A-F, Six Novel Mycosporine-Like Amino-Acids and a Novel Betaine from the Red Alga Bostrychia scorpioides. Mar. Drugs 2019, 17, 356. [CrossRef]

7. Oren, A.; Gunde-Cimerman, N. Mycosporines and Mycosporine-like Amino Acids: UV Protectants or Multipurpose Secondary Metabolites? FEMS Microbiol. Lett. 2007, 269, 1-10. [CrossRef]

8. Wada, N.; Sakamoto, T.; Matsugo, S. Mycosporine-Like Amino Acids and Their Derivatives as Natural Antioxidants. Antioxidants 2015, 4, 603-646. [CrossRef]

9. Lawrence, K.P.; Long, P.F.; Young, A.R. Mycosporine-Like Amino Acids for Skin Photoprotection. Curr. Med. Chem. 2018, 25, 5512-5527. [CrossRef]

10. Zuccarello, G.; Muangmai, N.; Preuss, M.; Sanchez, L. The Bostrychia tenella Species Complex: Morphospecies and Genetic Cryptic Species with Resurrection of B. binderi. Phycologia 2015, 54, 261-270. [CrossRef]

11. Orfanoudaki, M.; Hartmann, A.; Ngoc, H.N.; Gelbrich, T.; West, J.; Karsten, U.; Ganzera, M. Mycosporine-like Amino Acids, Brominated and Sulphated Phenols: Suitable Chemotaxonomic Markers for the Reassessment of Classification of Bostrychia calliptera (Ceramiales, Rhodophyta). Phytochemistry 2020, 174, 112344. [CrossRef]

12. Orfanoudaki, M.; Hartmann, A.; Kamiya, M.; West, J.; Ganzera, M. Chemotaxonomic Study of Bostrychia Spp. (Ceramiales, Rhodophyta) Based on Their Mycosporine-Like Amino Acid Content. Molecules 2020, 25, 3273. [CrossRef]

13. Mori, C.C.; Bagatini, I.L.; Garcia da Silva, T.; Parrish, C.C.; Henriques Vieira, A.A. Use of Fatty Acids in the Chemotaxonomy of the Family Selenastraceae (Sphaeropleales, Chlorophyceae). Phytochemistry 2018, 151, 9-16. [CrossRef]

14. Falshaw, R.; Furneaux, R.H. Chemotaxonomy of New Zealand Red Algae in the Family Gigartinaceae (Rhodophyta) Based on Galactan Structures from the Tetrasporophyte Life-Stage. Carbohydr. Res. 2009, 344, 210-216. [CrossRef]

15. Amico, V. Marine Brown Algae of Family Cystoseiraceae: Chemistry and Chemotaxonomy. Phytochemistry 1995, $39,1257-1279$. [CrossRef]

16. Xu, K.; Guo, S.; Jia, X.; Li, X.; Shi, D. Phytochemical and Chemotaxonomic Study on Leathesia nana (Chordariaceae). Biochem. Syst. Ecol. 2018, 81, 42-44. [CrossRef]

17. Jeffrey, S.; Mactavish, H.; Dunlap, W.; Vesk, M.; Groenewoud, K. Occurrence of UVA-and UVB-Absorbing Compounds in 152 Species (206 Strains) of Marine Microalgae. Mar. Ecol. Prog. Ser. 1999, 189, 35-51. [CrossRef] 
18. Geraldes, V.; de Medeiros, L.S.; Jacinavicius, F.R.; Long, P.F.; Pinto, E. Development and Validation of a Rapid LC-MS/MS Method for the Quantification of Mycosporines and Mycosporine-like Amino Acids (MAAs) from Cyanobacteria. Algal Res. 2020, 46, 101796. [CrossRef]

19. Whitehead, K.; Hedges, J.I. Analysis of Mycosporine-like Amino Acids in Plankton by Liquid Chromatography Electrospray Ionization Mass Spectrometry. Mar. Chem. 2002, 80, 27-39. [CrossRef]

20. Chaves-Peña, P.; de la Coba, F.; Figueroa, F.L.; Korbee, N. Quantitative and Qualitative HPLC Analysis of Mycosporine-Like Amino Acids Extracted in Distilled Water for Cosmetical Uses in Four Rhodophyta. Mar. Drugs 2019, 18, 27. [CrossRef] [PubMed]

21. Hartmann, A.; Murauer, A.; Ganzera, M. Quantitative Analysis of Mycosporine-like Amino Acids in Marine Algae by Capillary Electrophoresis with Diode-Array Detection. J. Pharm. Biomed. Anal. 2017, 138, 153-157. [CrossRef] [PubMed]

22. Hartmann, A.; Becker, K.; Karsten, U.; Remias, D.; Ganzera, M. Analysis of Mycosporine-Like Amino Acids in Selected Algae and Cyanobacteria by Hydrophilic Interaction Liquid Chromatography and a Novel MAA from the Red Alga Catenella Repens. Mar. Drugs 2015, 13, 6291-6305. [CrossRef] [PubMed]

23. Carreto, J.I.; Carignan, M.O.; Montoya, N.G. A High-Resolution Reverse-Phase Liquid Chromatography Method for the Analysis of Mycosporine-like Amino Acids (MAAs) in Marine Organisms. Mar. Biol. 2005, 146, 237-252. [CrossRef]

24. Sun, Y.; Zhang, N.; Zhou, J.; Dong, S.; Zhang, X.; Guo, L.; Guo, G. Distribution, Contents, and Types of Mycosporine-Like Amino Acids (MAAs) in Marine Macroalgae and a Database for MAAs Based on These Characteristics. Mar. Drugs 2020, 18, 43. [CrossRef]

25. Figueroa, F.L.; Korbee, N.; de Clerck, O.; Bárbara, I.; Gall, E.A.R. Characterization of Grateloupia lanceola (Halymeniales, Rhodophyta), an Obscure Foliose Grateloupia from the Iberian Peninsula, Based on Morphology, Comparative Sequence Analysis and Mycosporine-like Amino Acid Composition. Eur. J. Phycol. 2007, 42, 231-242. [CrossRef]

26. Hotter, V.; Glaser, K.; Hartmann, A.; Ganzera, M.; Karsten, U. Polyols and UV-Sunscreens in the Prasiola-Clade (Trebouxiophyceae, Chlorophyta) as Metabolites for Stress Response and Chemotaxonomy. J. Phycol. 2018, 54, 264-274. [CrossRef]

27. Llewellyn, C.A.; Greig, C.; Silkina, A.; Kultschar, B.; Hitchings, M.D.; Farnham, G. Mycosporine-like Amino Acid and Aromatic Amino Acid Transcriptome Response to UV and Far-Red Light in the Cyanobacterium Chlorogloeopsis fritschii PCC 6912. Sci. Rep. 2020, 10, 20638. [CrossRef]

28. Portwich, A.; Garcia-Pichel, F. Biosynthetic Pathway of Mycosporines (Mycosporine-like Amino Acids) in the Cyanobacterium Chlorogloeopsis Sp. Strain PCC 6912. Phycologia 2003, 42, 384-392. [CrossRef] 